\title{
Accreditation of specialized asthma units for adults in Spain: an applicable experience for the management of difficult-to-control asthma
}

This article was published in the following Dove Press journal:

Journal of Asthma and Allergy

9 May 2017

Number of times this article has been viewed

\section{Carolina Cisneros' \\ Rocío Magdalena Díaz- \\ Campos $^{2}$ \\ Núria Marina ${ }^{3}$ \\ Carlos Melero \\ Alicia Padilla ${ }^{4}$ \\ Silvia Pascual ${ }^{5}$ \\ Celia Pinedo ${ }^{6}$ \\ Andrea Trisán ${ }^{7}$ \\ On behalf of the DUMA \\ Study Group \\ 'Service of Pneumology, Hospital Universitario de La Princesa, ${ }^{2}$ Service of Pneumology, Hospital Universitario 12 de Octubre, Madrid, ${ }^{3}$ Asthma Unit, Laboratorio de Exploración Funcional, Department of Pneumology, Hospital Universitario Cruces, BioCruces, Barakaldo, Bizkaia, ${ }^{4}$ Agencia Sanitaria Costal de Sol, Marbella, Málaga, ${ }^{5}$ Service of Pneumology, Hospital de Galdakao, Bizkaia, ${ }^{6}$ Service of Pneumology, Hospital Clínico San Carlos, ${ }^{7}$ Service of Pneumology, Hospital Universitario Puerta de Hierro, Madrid, Spain}

Correspondence: Carolina Cisneros Service of Pneumology, Hospital Universitario de La Princesa, Calle de Diego León 62, E-28006 Madrid, Spain Tel +34 915202200 Email carol9199@yahoo.es

\begin{abstract}
This paper, developed by consensus of staff physicians of accredited asthma units for the management of severe asthma, presents information on the process and requirements for already-existing asthma units to achieve official accreditation by the Spanish Society of Pneumology and Thoracic Surgery (SEPAR). Three levels of specialized asthma care have been established based on available resources, which include specialized units for highly complex asthma, specialized asthma units, and basic asthma units. Regardless of the level of accreditation obtained, the distinction of "excellence" could be granted when more requirements in the areas of provision of care, technical and human resources, training in asthma, and teaching and research activities were met at each level. The Spanish experience in the process of accreditation of specialized asthma units, particularly for the care of patients with difficult-to-control asthma, may be applicable to other health care settings.
\end{abstract}

Keywords: asthma unit, severe asthma, uncontrolled asthma, asthma treatment

\section{Introduction}

Asthma in adults is a heterogeneous disease usually characterized by chronic airway inflammation with hyperresponsiveness of airways to various stimuli. The prevalence estimates of asthma, in general, and the prevalence of severe asthma, in particular, are well known and sufficiently illustrative. According to the Global Asthma Report $2014,{ }^{1}$ asthma affects 334 million people with projections of 400 million in 2025 . In addition, asthma still accounts for one of every 250 deaths worldwide, and almost all of these deaths are avoidable. ${ }^{2}$ In Spain, prevalence rates of 5\% and $10 \%$ have been estimated in adults and children, respectively, with more than three million people with asthma. ${ }^{3-5}$ In addition, there is a large geographical variability is asthma prevalence, with a trend toward stabilization following an increase in the prevalence of the disease observed in the past years. ${ }^{3,6}$ This complex disease affects patients of all ages. Although its diagnosis is usually easily established and most patients respond to therapy, approximately between $3 \%$ and $10 \%$ of adult asthma patients have disease that is difficult to control despite taking maximal doses of inhaled medications. ${ }^{7}$ Patients with therapy-resistant or difficult-to-control asthma require a rigorous and systematic approach to their diagnosis and treatment. Despite rigorous, optimized follow-up treatment, $75 \%$ of severe asthma patients did not achieve adequate symptom control and presented with impaired quality of life. ${ }^{8}$

Although much progress has been made in the understanding of difficult-tocontrol asthma, with consensus documents and clinical practice guidelines focused 
on severe uncontrolled asthma with proposals for a stepwise diagnostic procedure and phenotype-targeted treatment,, 90 improvements in clinical practice are still limited. In addition, involvement of pulmonology services in the specialized approach for difficult-to-control asthma is insufficient. In a survey carried out in Spain, 47 (68.1\%) of a total of 69 pulmonology services met criteria for an important level of health care activity in asthma, but only 29 (42\%) had a monographic consultation for difficult-to-control asthma and $37(53.6 \%)$ had implemented an education program. As for post-graduate education, only $31(44.9 \%)$ provided their resident physicians with specific asthma training. ${ }^{11}$

In 2015, the asthma area of the Spanish Society of Pneumology and Thoracic Surgery (SEPAR) addressed the task of establishing the necessary requirements for the provision of official accreditation standards of the different levels of care for asthma units already existing in hospitals of the Spanish National Healthcare System. Accreditation levels included basic units, specialized units, or specialized units of high complexity, with or without the distinctive of excellence, according to the fulfillment of a series of criteria established by the society.

The development and implementation of this nationwide strategic plan had several objectives, including improving the care and quality of life of asthma patients, particularly patients with severe difficult-to-control asthma in order to achieve a decrease and prevention of acute exacerbations, with a subsequent reduction in the number of visits to the emergency department, need of in-patient care, and inadequate use of asthma medications. All these actions have been complemented by the development and implementation of education and self-management strategies (where nursing plays a key and indispensable role) and follow-up of patients in monographic consultations for asthma and in the framework of multidisciplinary involvement of health care professionals.

In a recent scientific meeting of health care professionals of the different asthma units, which underwent specialized accreditation, it was agreed that a perspective article should be drafted to achieve greater dissemination of the details regarding the characteristics, service portfolio, and resources available in these units. The present document written and approved by all attendees of this event and members of units provides information and describes the initial global experience of asthma units accredited in Spain. It also aims to contribute to raising awareness among pulmonologists and other professionals about the problem of severe refractory asthma and the response offered by asthma units to improve patient care and to minimize the complications and burden of this complex pathology. In this respect, we believe that the Spanish experience may be useful and potentially applicable to other settings, in particular with similar health care systems. However, workup details and assessment of outcomes were outside the scope of this report.

\section{Difficult-to-control asthma}

Significant progress and advances in the understanding of asthma and in the care of asthma patients with an increase in the number of medications and development of new protocolized therapeutic strategies have been associated with a substantial reduction in asthma-specific mortality and hospitalization rates for asthma. However, despite all these improvements and the development of clinical practice guidelines with specific recommendations for the control of asthma, it is well known that in clinical practice, adequate asthma control is achieved in only one-third of patients. ${ }^{12-14}$

Uncontrolled severe asthma accounts for $\sim 15 \%$ of all asthma patients but is associated with a higher morbidity and mortality as well as an important impact on health care costs and the consumption of resources. ${ }^{15}$ The AsmaCost study ${ }^{16}$ based on data of a prospective cohort of 627 patients throughout Spain with asthma diagnosed according to the guidelines of the Global Initiative for Asthma (GINA) ${ }^{17}$ and the adapted Spanish criteria (Guía Española de Manejo del Asma [GEMA]) ${ }^{9}$ and followed up for 12 months revealed that the total societal cost for asthma was $1,726 €$ per patient annually $(1,533 €$ to the National Health Service), with higher costs for patients older than 65 years and for those with a more severe disease $(2,635 €$ for severe asthma). Based on these findings, the total annual cost of asthma in Spain was estimated to be 1,480 million euros. On the other hand, $70 \%$ of total costs were attributed to the poor control of the disease, which further reinforces the need to achieve clinical stability of the patients as it has been repeatedly emphasized in clinical practice guidelines. ${ }^{9,17}$

From another perspective, poor asthma control is a determining factor of the high indirect costs related to absenteeism and reduced productivity. In a naturalistic and observational study (TENOR study) of 4,756 asthma patients recruited in 283 study sites from diverse geographical areas in the USA and followed up for 24 months, the mean annual costs for uncontrolled patients with difficult-to-treat asthma were more than double of those for controlled patients throughout the study. ${ }^{18}$ Different studies carried out in other countries have obtained similar results. ${ }^{19-21}$ Moreover, chronic comorbidities contribute to the burden and costs of persistent asthma, ${ }^{22}$ and poor adherence to asthma medication regimens, including 
patients with difficult-to-control asthma, is a key problem contributing to poor disease control. ${ }^{23}$ Adherence to asthma treatment in patients with uncontrolled difficult asthma is highly relevant, since treatments currently considered for step-up therapy (biologics, bronchial thermoplasty) ${ }^{9,17}$ are very expensive and, in many cases, are prescribed without adequate adherence to drug regimens in the lower steps. ${ }^{24}$

A further interesting aspect concerns to deficiencies in the development and implementation of effective education programs for asthma patients, promotion of health, and social support. It has been demonstrated that education in self-management of asthma with symptom or peak flow monitoring, combined with regular medical visits and written action plans, is effective in improving health outcomes in adults with asthma. ${ }^{25,26}$ In a 1-year cluster randomized controlled multicenter study with the participation of 230 adults with mild-to-moderate persistent uncontrolled asthma, an asthma educational program based on a repeated short intervention, given in four face-to-face sessions at 3-month intervals was effective in improving asthma symptom control, future risk, and quality of life. ${ }^{27}$ In this study, the education program included administration of a written personalized action plan and training on inhaler technique. ${ }^{27}$ Other experiences reported similar results. In a controlled clinical trial in which a comprehensive asthma intervention program was evaluated in a population of Medicaid-insured asthmatic children, a significant improvement in health outcomes (emergency department visits, hospitalizations) and asthma health care costs was observed in the intervention group in the year after enrollment. ${ }^{28}$ In a randomized patient selection study with crossover, a vigorous medical regimen and intensive educational program were able to decrease hospital use among a group of adult asthmatics who had previously required repeated readmissions for acute asthma exacerbations. ${ }^{29}$ In a large teaching hospital (Glasgow Royal Infirmary) where asthma management was audited prospectively for 1 year, treatment of asthma patients in wards with a specialist interest in respiratory medicine was associated with a reduction in the rate of readmissions compared to patients admitted to general wards without this special interest ( $2 \%$ vs. $20 \%$ ). ${ }^{30}$

Given the complexity and multiple factors involved in the control of asthma, there is a need for establishing asthma units involved in the care of asthma patients, especially those patients with severe difficult-to-control disease. However, up to the present time, a few studies have demonstrated that assessment and management of patients in specific units for severe asthma are associated with substantial benefits in terms of health (asthma control, quality of life) and reduction in economic burden. In a study of 346 patients with severe asthma referred to specialist centers across the UK and followed up for a median of 286 days, significant reductions in health-care use (primary care or emergency department visits), hospital admissions, and steroid dose were observed, which were accompanied by significant improvements in quality of life and asthma control. ${ }^{31}$ In a crossover study carried out in Spain, treatment of patients in asthma clinics was cost-effective and beneficial in asthma management in comparison with standard outpatient services. ${ }^{32}$ The National Asthma Program in Finland, probably one of the most outstanding health care networks for asthma patients, has shown that integration of different health care levels involved in the management of asthma (pneumologists, primary care physicians, and pharmacists) improves control of the disease and reduces the morbidity of asthma. ${ }^{33}$

\section{Specialized asthma units}

The SEPAR has promoted the task of accrediting the levels of the different asthma units already existing in our country, with the following objectives: 1) to improve the level of care of asthma patients, ensuring a framework of quality of care; 2) to establish resources and facilitating their management; 3) to promote the development of training plans in asthma and to advance in the concept of "accreditation of knowledge"; 4) to favor collaboration with professionals from other clinical disciplines in a cooperative environment; and 5) to promote asthma research. Within the SEPAR training framework, a manual on severe asthma and difficult-tocontrol asthma has been published, which includes a chapter on the provision and organization of a severe asthma unit. ${ }^{34}$

Briefly, three levels of specialized asthma care have accredited based on available resources: specialized unit for highly complex asthma, specialized asthma unit, and basic asthma unit. The characteristics of these three grades of accreditation are detailed in Table 1. Regardless of the level of accreditation obtained, the distinction of "excellence" could be granted when more requirements were met at each level. In order to obtain accreditation at each of the levels, there were indispensable requirements (IRs) that had to be met; also, there were two other criteria, which included evaluable criteria (EC) and recommended criteria (RC). The certification of each level was achieved if at least $80 \%$ of the EC corresponding to each category were fulfilled. The quality of each level was "excellent" if the result of the formula $(\mathrm{EC}+\mathrm{RC}) \times 100 /($ total number of $\mathrm{EC}+\mathrm{RC}$ items at the level) was $\geq 80 \%$. 
Table I Criteria requested for accreditation of the different levels of asthma units by the Spanish Society of Pneumology and Thoracic Surgery (SEPAR)

\begin{tabular}{|c|c|c|c|}
\hline Activities & $\begin{array}{l}\text { Specialized unit for highly complex } \\
\text { asthma }\end{array}$ & Specialized asthma unit & Basic asthma unit \\
\hline $\begin{array}{l}\text { Health care } \\
\text { activity }\end{array}$ & $\begin{array}{l}\text { Stable functioning organigram } \\
\text { Availability of a physical space for } \\
\text { consultations and complementary studies } \\
\text { Provision of informatics systems, databases, } \\
\text { documentation files, and action protocols } \\
\text { Number of asthma patients attended } \\
\text { annually between } 500 \text { and I,000 } \\
\text { Possibility of providing emergency care for } \\
\text { patients with acute exacerbations without } \\
\text { the need of hospital admission, }>50 / \text { year } \\
\text { Coordinated activity with other specialists } \\
\text { (allergy, ear, nose, and throat, and } \\
\text { pediatrics) is advisable } \\
\text { Standardized education program }\end{array}$ & $\begin{array}{l}\text { Stable functioning organigram } \\
\text { Availability of a physical space for consultations and } \\
\text { complementary studies } \\
\text { Health care and education protocols } \\
\text { Number of asthma patients attended annually } \\
\text { between } 250 \text { and } 500 \\
\text { Possibility of providing emergency care for patients } \\
\text { with acute exacerbations without the need of } \\
\text { hospital admission } \\
\text { The presence of a database is advisable } \\
\text { Coordinated activity with other specialists (allergy, } \\
\text { ear, nose, and throat, and pediatrics) is advisable }\end{array}$ & $\begin{array}{l}\text { Stable organigram } \\
\text { Number of asthma patients } \\
\text { attended annually between } 100 \\
\text { and } 250\end{array}$ \\
\hline $\begin{array}{l}\text { Technical } \\
\text { resources } \\
\text { Human } \\
\text { resources }\end{array}$ & $\begin{array}{l}\text { Specific physical space } \\
\text { Office and clinical material } \\
\text { Multidisciplinary group of health care } \\
\text { professionals specialized in asthma, with a } \\
\text { specialist in pneumology as the head of the } \\
\text { unit, and at least three staff physicians } \\
\text { At least two nurses } \\
\text { Other possible members of the unit: at } \\
\text { least two scholars (recommendable) with } \\
\text { optional one allergologist and a psychologist }\end{array}$ & $\begin{array}{l}\text { Specific physical space } \\
\text { Office and clinical material } \\
\text { A specialist in pneumology as the head of the unit, } \\
\text { with at least two staff physicians } \\
\text { At least one nurse } \\
\text { At least one scholar (recommendable) }\end{array}$ & $\begin{array}{l}\text { Specific physical space } \\
\text { Office and clinical material } \\
\text { Activity developed by a specialist } \\
\text { in pneumology }\end{array}$ \\
\hline $\begin{array}{l}\text { Accredited } \\
\text { training in } \\
\text { asthma }\end{array}$ & $\begin{array}{l}\text { Teachers or attendees (participants) of } \\
\text { accredited courses on asthma, at the level } \\
\text { of the autonomous communities or given by } \\
\text { SEPAR, or that some of the staff members } \\
\text { had taken accredited international courses } \\
\text { on asthma or a master in asthma } \\
\text { Recommendable to have been a member } \\
\text { of the Emerging Asthma Group (Grupo } \\
\text { Emergente Asma [GEA]) of the SEPAR }\end{array}$ & $\begin{array}{l}\text { Evaluable criteria (EC) that some of the staff } \\
\text { members have been teachers or attendees } \\
\text { (participants) of accredited courses on asthma at } \\
\text { the autonomous community level or given by SEPAR } \\
\text { EC that some of the staff members had taken } \\
\text { accredited international courses on asthma or a } \\
\text { master in asthma } \\
\text { Recommendable that at least some member of } \\
\text { the unit belongs to or has been taking part in the } \\
\text { Emerging Asthma Group (GEA) of the SEPAR }\end{array}$ & $\begin{array}{l}\text { Indispensable to have been } \\
\text { taken part in accredited courses } \\
\text { on asthma at the level of the } \\
\text { autonomous communities } \\
\text { or given by SEPAR, other } \\
\text { accredited international courses } \\
\text { on asthma or a master in asthma } \\
\text { Recommendable to have been a } \\
\text { member of the Emerging Asthma } \\
\text { Group (GEA) of the SEPAR }\end{array}$ \\
\hline $\begin{array}{l}\text { Teaching } \\
\text { activity }\end{array}$ & $\begin{array}{l}\text { Pre-graduate and post-graduate teaching } \\
\text { activity } \\
\text { At least one of the staff members should } \\
\text { have the academic degree of Doctorate in } \\
\text { Medicine } \\
\text { Study project or doctoral thesis related } \\
\text { with asthma directed by the unit in the last } \\
5 \text { years }\end{array}$ & $\begin{array}{l}\text { Pre-graduate and post-graduate teaching activity } \\
\text { Recommendable that at least one the staff members } \\
\text { has the academic degree of Doctorate in Medicine } \\
\text { Recommendable to have the direction of a doctoral } \\
\text { thesis on asthma in the last } 5 \text { years }\end{array}$ & Not requested at this level \\
\hline $\begin{array}{l}\text { Research } \\
\text { activity }\end{array}$ & $\begin{array}{l}\text { Minimal mandatory activity: at least five } \\
\text { original articles published in journals with } \\
\text { impact factor, recommendable at least two } \\
\text { research projects financed by SEPAR, and at } \\
\text { least participation in two projects in which } \\
\text { the Integrated Research Program (IRP) of } \\
\text { asthma of SEPAR would have been involved } \\
\text { Participation in clinical trials of asthma } \\
\text { It is recommendable the participation } \\
\text { in research projects of the Biomedical } \\
\text { Research Networking Centers (CIBER) and } \\
\text { having obtained Fondo de Investigación en } \\
\text { Salud (FIS) grants for some research project } \\
\text { of the unit in the last } 5 \text { years }\end{array}$ & $\begin{array}{l}\text { Minimal mandatory activity: at least two original } \\
\text { articles published in journals with impact factor, } \\
\text { recommendable at least one research project } \\
\text { financed by SEPAR, and at least participation in one } \\
\text { project in which the IRP of asthma of SEPAR would } \\
\text { have been involved } \\
\text { Recommendable to develop clinical trials of asthma }\end{array}$ & $\begin{array}{l}\text { Recommendable that in the last } \\
5 \text { years, there has been an article } \\
\text { published in a journal with } \\
\text { impact factor and participation } \\
\text { in a project financed by SEPAR } \\
\text { or in projects in which the IRP } \\
\text { of SEPAR would have been } \\
\text { involved }\end{array}$ \\
\hline
\end{tabular}


Table I (Continued)

\begin{tabular}{lll}
\hline & $\begin{array}{l}\text { Specialized unit for highly complex } \\
\text { asthma }\end{array}$ & Specialized asthma unit \\
\hline $\begin{array}{l}\text { Representative } \\
\text { activity }\end{array}$ & $\begin{array}{l}\text { Mandatory participation in asthma health } \\
\text { promotion activities under the auspices } \\
\text { of health care systems of the autonomous }\end{array}$ & $\begin{array}{l}\text { Recommendable to belong or to have been a } \\
\text { member of the Executive Committee of the Asthma }\end{array}$ \\
$\begin{array}{ll}\text { communities, the Spanish national health } \\
\text { care system or international health care }\end{array}$ & $\begin{array}{l}\text { IRP of asthma of SEPAR or a member of working } \\
\text { systems, or public or private bodies }\end{array}$ & \begin{tabular}{l} 
or international societies \\
\hline
\end{tabular}
\end{tabular}

The integral care of the patient with severe asthma in a specialized multidisciplinary and high-quality setting presents many advantages, particularly related to the diagnosis of asthma, including identification of patients according to phenotypes, treatment of comorbidities, protocolized followup, optimization of the therapeutic arsenal, indication of specific treatments, and emphasis on health education for both patients and health care professionals. For instance, to have available a specialized nurse well trained in asthma education and use of inhaler devices will result in a better understanding of the disease, adherence to treatment, and control of the disease. In addition, there is a high prevalence of psychocomorbidity in asthma, and acting at this level can improve the quality of life of the patients, control of anxiety, low consumption of resources, etc. In this respect, psychological support may be recommendable. Likewise, the possibility of implementing complementary programs contributes to better control of the disease. This approach is associated with cost savings as a result of a better and rational use of the resources. In addition, accredited asthma units could help patients with asthma through identifying misdiagnosed cases of asthma and providing more appropriate treatment/referral. Misdiagnosis of non-asthmatic conditions as uncontrolled asthma has been reported to be as high as $12 \%-30 \% .^{35,36}$ The implementation of databases with relevant and updated clinical information is an essential tool for the independent analysis of the data of each unit or aggregated data from different units. This tool would also facilitate the development and participation in research projects.

This is effectively a proposal for the control and improvement of care provided to our patients, the results of which are pending to be collected and evaluated. We believe that diagnosis and treatment by highly specialized and experienced personnel in asthma will result in the achievement of a better control of disease. A recent study carried out in an asthma clinic of a university-affiliated hospital in Lugo in 2012 showed that all cost variables except drugs and diagnostic tests were significantly reduced in comparison with standard outpatient services, giving an annual saving per patient of $€ 338 .{ }^{32}$

\section{Concluding remarks}

The assessment and management of patients with severe difficult-to-control asthma in accredited asthma units aims to improve the quality of care and control of the disease. In addition, specialized asthma units can improve the costeffectiveness of pharmaceutical expenditure, especially regarding the new and costly therapies. Health care professionals involved in the management of asthma should continue pursuing for unifying the quality of care of patients with asthma in a multidisciplinary collaborative setting.

\section{Acknowledgments}

The authors are grateful to Novartis for the logistic support and to Marta Pulido, MD, PhD, for editing the manuscript and for the editorial assistance.

The following are the members of "The DUMA Study Group" (DUMA is the Spanish acronym for Development of Monographic Asthma Units.): Vicente Plaza Moral, Hospital de la Santa Creu i Sant Pau, Barcelona, Spain; Isabel Urrutia Landa, Hospital de Galdakao, Bizkaia, Spain; Carlos Villasante, Hospital Universitario La Paz, Madrid, Spain; Xavier Muñoz, Hospital Universitari Vall d'Hebron, CIBERES, Barcelona, Spain; Núria Marina Malanda, Hospital Universitario de Cruces, Barakaldo, Bizkaia, Spain; Carlos Melero Moreno, Hospital Universitario 12 de Octubre, Madrid, Spain; Francisco Javier Álvarez Gutiérrez, Hospital Universitario Virgen del Rocío, Sevilla, Spain; Alicia Padilla Galo, Agencia Sanitaria Costa del Sol, Marbella, Málaga, Spain; Celia Pinedo Sierra, Hospital Universitario Clínico San Carlos, Madrid, Spain; Luís Pérez de Llano, Hospital Universitario Lucus Augusti (HULA), Lugo, Spain; Vicente Antolín López Viña, Hospital Universitario Puerta de Hierro, Madrid, Spain; Borja Cosío, Hospital Universitario Son Espases, CIBERES, Palma de Mallorca, Spain; Carolina Cisneros Serrano, Hospital Universitario de La Princesa, Madrid, Spain; Eva Martínez Moragón, Hospital Universitari Doctor Peset, Valencia, Spain; Gregorio Soto Campos, Hospital de Jerez, Cádiz, Spain; Julia García, Hospital General Universitario Gregorio Marañón, Madrid, Spain; José Serrano Pariente, Hospital Comarcal de Inca, Inca, Mallorca, Islas 
Baleares, Spain; Bernardino Alcázar Navarete, Hospital de Alta Resolución de Loja, Granada, Spain; Beatriz Arias, Hospital Universitario Infanta Leonor, Madrid, Spain; Juan Ortiz, Hospital del Bierzo, León, Spain; Cleofé Fernández, Hospital General Universitario de Alicante, Alicante, Spain; Rosa Irigarai, Hospital de Manacor, Manacor, Mallorca, Islas Baleares, Spain; and César Picado, Hospital Clinic, Universitat de Barcelona, CIBERES, Barcelona, Spain.

\section{Disclosure}

The authors report no conflicts of interest in this work.

\section{References}

1. Global Asthma Network. The Global Asthma Report 2014. Auckland, New Zealand: Global Asthma Network; 2014. Available from: http://www.globalasthmanetwork.org/publications/Global_Asthma_ Report_2014.pdf. Accessed April 2, 2016.

2. Masoli M, Fabian D, Holt S, Beasley R; Global Initiative for Asthma (GINA) Program. The global burden of asthma: executive summary of the GINA dissemination committee report. Allergy. 2004;59(5): 469-478.

3. García-Marcos L, Quirós AB, Hernández GG, et al. Stabilization of asthma prevalence among adolescents and increase among schoolchildren (ISAAC phases I and III) in Spain. Allergy. 2004;59(12):1301-1307.

4. GEMA [homepage on the Internet]. Spanish Guideline on the Management of Asthma. GEMA 4.1. Available from: http://www.gemasma.com. Accessed April 2, 2014.

5. Urrutia I, Aguirre U, Sunyer J, et al; Estudio de Salud Respiratoria de la Comunidad Europea. Changes in the prevalence of asthma in the Spanish cohort of the European Community Respiratory Health Survey (ECRHS-II). Arch Bronconeumol. 2007;43(8):425-430.

6. Chinn S, Jarvis D, Burney P, et al. Increase in diagnosed asthma but not in symptoms in the European Community Respiratory Health Survey. Thorax. 2004;59(8):646-651.

7. Strek ME. Difficult asthma. Proc Am Thorac Soc. 2006;3(1):116-123.

8. Athanazio R, Carvalho-Pinto R, Fernandes FL, et al. Can severe asthmatic patients achieve asthma control? A systematic approach in patients with difficult to control asthma followed in a specialized clinic. BMC Pulm Med. 2016;16(1):153.

9. Le AV, Simon RA. The difficult-to-control asthma: a systematic approach. Allergy Asthma Clin Immunol. 2006;2(3):109.

10. Cisneros Serrano C, Melero Moreno C, Almonacid Sánchez C, et al. Guidelines for severe uncontrolled asthma. Arch Bronconeumol. 2015;51(5):235-246.

11. Plaza V, Bellido-Casado J, Díaz C, et al. Involvement of Spanish pulmonology centers in patient care, postgraduate education and research in asthma: the results of the ATENEA survey. Arch Bronconeumol. 2012; 48(4):114-119.

12. Fueyo A, Ruiz MA, Ancochea J, Guilera M, Badia X; ESCASE Group. Asthma control in Spain. Do season and treatment pattern matter? The ESCASE study. Respir Med. 2007;101(5):919-924.

13. Olaguibel JM, Quirce S, Juliá B, et al; MAGIC Study Group. Measurement of asthma control according to Global Initiative for Asthma guidelines: a comparison with the Asthma Control Questionnaire. Respir Res. 2012;13:50.

14. López-Viña A, Cimas JE, Díaz Sánchez C, et al; Scientific Committee of ASES study. A comparison of primary care physicians and pneumologists in the management of asthma in Spain: ASES study. Respir Med. 2003;97(8):872-881.
15. Quirce S, Plaza V, Picado C, Vennera M, Casafont J. Prevalence of uncontrolled severe persistent asthma in pneumology and allergy hospital units in Spain. J Invest Allergol Clin Immunol. 2011;21(6):466-471.

16. Martínez-Moragón E, Serra-Batllés J, De Diego A, et al; por el Grupo de Investigadores del estudio AsmaCost. Economic cost of treating the patient with asthma in Spain: the AsmaCost study. Arch Bronconeumol. 2009;45(10):481-486.

17. Global Initiative for Asthma (GINA) [homepage on the Internet]. From the Global Strategy for Asthma Management and Prevention. Available from: http://www.ginasthma.org/. Accessed April 2, 2016.

18. Sullivan SD, Rasouliyan L, Russo PA, Kamath T, Chipps BE, TENOR Study Group. Extent, patterns, and burden of uncontrolled disease in severe or difficult-to-treat asthma. Allergy. 2007;62(2):126-133.

19. Sculpher MJ, Price M. Measuring costs and consequences in economic evaluation in asthma. Respir Med. 2003;97(5):508-520.

20. Mukherjee M, Stoddart A, Gupta RP, et al. The epidemiology, healthcare and societal burden and costs of asthma in the UK and its member nations: analyses of standalone and linked national databases. BMC Med. 2016;14(1): 113 .

21. Tan NC, Nguyen HV, Lye WK, Sankari U, Nadkarni NV. Trends and predictors of asthma costs: results from a 10-year longitudinal study. Eur Respir J. 2016;47(3):801-809.

22. Kauppi P, Linna M, Jantunen J, et al. Chronic comorbidities contribute to the burden and costs of persistent asthma. Mediators Inflamm. 2015; 2015:819194.

23. Braido F, Baiardini I, Blasi F, Pawankar R, Canonica GW. Adherence to asthma treatments: 'we know, we intend, we advocate'. Curr Opin Allergy Clin Immunol. 2015;15(1):49-55.

24. Gamble J, Stevenson M, McClean E, Heaney LG. The prevalence of nonadherence in difficult asthma. Am J Respir Crit Care Med. 2009; 180(9):817-822.

25. Gibson PG, Powell H, Coughlan J, et al. Self-management education and regular practitioner review for adults with asthma. Cochrane Database Syst Rev. 2003;1:CD001117.

26. Powell H, Gibson PG. Options for self-management education for adults with asthma. Cochrane Database Syst Rev. 2003;1:CD004107.

27. Plaza V, Peiró M, Torrejón M, et al; PROMETHEUS Study Group. A repeated short educational intervention improves asthma control and quality of life. Eur Respir J. 2015;46(5):1298-1307.

28. Kelly CS, Morrow AL, Shults J, Nakas N, Strope GL, Adelman RD. Outcomes evaluation of a comprehensive intervention program for asthmatic children enrolled in medicaid. Pediatrics. 2000;105(5):1029-1035.

29. Mayo PH, Richman J, Harris HW. Results of a program to reduce admissions for adult asthma. Ann Intern Med. 1990;112(11):864-871.

30. Bucknall CE, Robertson C, Moran F, Stevenson RD. Differences in hospital asthma management. Lancet. 1988;1(8588):748-750.

31. Gibeon D, Heaney LG, Brightling CE, et al. Dedicated severe asthma services improve health-care use and quality of life. Chest. 2015;148(4): 870-876.

32. Pérez de Llano LA, Villoro R, Merino M, et al. Cost effectiveness of outpatient asthma clinics. Arch Bronconeumol. 2016;52(4):196-203.

33. Haahtela T, Tuomisto LE, Pietinalho A, et al. A 10 year asthma programme in Finland: major change for the better. Thorax. 2006;61(8): 663-670.

34. Pérez de Llano LA. Dotación y organización de una unidad de asma grave. In: Plaza V, López-Viña A, Quirce S, editors. Asma grave y asma de control dificil. Madrid: Sanidad Y Ediciones (SANED), S.L.; 2013:3-18.

35. Robinson DS, Campbell DA, Durham SR, et al; Asthma and Allergy Research Group of the National Heart and Lung Institute. Systematic assessment of difficult-to-treat asthma. Eur Respir J. 2003;22(3): 478-483.

36. Aaron SD, Vandemheen KL, Boulet LP, et al; Canadian Respiratory Clinical Research Consortium. Overdiagnosis of asthma in obese and nonobese adults. CMAJ. 2008;179(11):1121-1131. 
Journal of Asthma and Allergy

The Journal of Asthma and Allergy is an international, peer-reviewed open access journal publishing original research, reports, editorials and commentaries on the following topics: Asthma; Pulmonary physiology; Asthma related clinical health; Clinical immunology and the immunological basis of disease; Pharmacological interventions and new therapies. This journal is included in PubMed. The manuscript management system is completely online and includes a very quick and fair peer-review system, which is all easy to use. Visit http://www. dovepress.com/testimonials.php to read real quotes from published authors.

Submit your manuscript here: https://www.dovepress.com/journal-of-asthma-and-allergy-journal 